\title{
A DYNAMIC REGION SURGING INTO THE NEW DECADE
}

\section{Eric A. McVadon, (USA)}

Contemplating the coming decade for China, Russia, Mongolia and the Central Asian states is an exciting undertaking. Central Asia and Northeast Asia are among the most dynamic areas on the globe today. These areas have seen sweeping change recently, are changing dramatically now, and undoubtedly will continue to change significantly in the coming decade. Many of the important changes that have occurred and are occurring now have been unexpected; indeed, some of those changes are startling. To illustrate, here are some highlights:

- China, despite persistent forecasts of economic disaster by Western economists and others, continued, right through the 1997 Asia financial crisis, to demonstrate success in its long-proclaimed foremost goal: national economic progress. China is consistently succeeding in economic growth even while its neighbors with very different economies - market economies more to the liking of most of us - have stumbled; but it now faces the enormous domestic challenges of WTO membership. There are also intriguing developments associated with the mainland's extensive economic links to a suddenly ailing Taiwan economy. Moreover, China, although initially snubbed by the Bush administration, has expressed solidarity with the United States in the war on terrorism and is at least tolerating the presence of U.S. forces near its western border, which might be viewed as closing a circle of containment. Who might have forecast that a year ago on April's Fool Day of 2001, when the disabled U.S. Navy EP-3 surveillance aircraft had landed on Hainan?

${ }^{1}$ Additionally, the posture of the roughly 100,000-strong U.S. forward-deployed forces in Asia has been altered recently by the increased availability and utility of Singapore for U.S. forces, most notably a pier built to accommodate the largest aircraft carrier, and the return last year to the Philippines of U.S. troops, albeit in small numbers and for limited purposes. These developments coupled with extensive and apparently enduring U.S. basing and operations from some of the Central Asian states (particularly the nature of the activity in Uzbekistan) and Pakistan as well as the large-scale operations in Afghanistan, which borders China, must look to many Chinese to be a manifestation of the containment of China they often assert is the U.S. goal. However, surprisingly, Beijing has not officially or noisily taken Washington to task on this issue, despite Chinese press reports calling attention to it. 
- Russia, while remaining on the ailing list economically and barely stable politically, has largely surmounted Soviet-era animosities and forged new links with both China and the United States. Moscow has apparently accepted a new strategic paradigm including continuing NATO expansion (probably to within a couple of hours' drive from St. Petersburg), imminent U.S. abrogation of the Anti-Ballistic Missile Treaty, and an ambitious program of prospective missile defenses for the United States - all the while becoming the primary supplier of major weapon systems to China: quiet and capable submarines, big destroyers with very potent and elusive anti-ship cruise missiles, fourth-generation fighter aircraft reaching into the hundreds, and more.

- Central Asia, including Afghanistan for this examination, has been transformed from the back of beyond to a central position on the world's politicomilitary stage. The five Central Asian states, formerly part of the Soviet Union, about a decade ago came to the attention of their neighbors and the world as new republics, then in the mid-1990s as part of the Shanghai Five and more recently as members of the Shanghai Cooperation Organization, along with Russia and China. Mention of these organizational names is rarely heard now. Nevertheless, most of the individual countries, even Uzbekistan, are now frequently mentioned in U.S. news reports. Afghanistan, has achieved notoriety over just two decades as the site of a major Soviet military debacle, a country subsequently subjected to collapse into political and social chaos, and now the scene of a riveting military spectacle, pitting radical technology against radical ideology. Remarkably, Afghanistan appears to be on its way to becoming essentially a new, possibly democratic, country, with at least a reasonable prospect of success in that endeavor. One cannot help but wonder what these extraordinary developments imply for the other five states of Central Asia.

- Mongolia, starting a decade earlier, has achieved undeniable demoratic status since the abrupt but welcome relief from Soviet domination a decade ago. There were many formidable obstacles for Mongolia to overcome - and many remain; but it is demonstrating the strength, resilience, and innovative abilities of its remarkable people. Mongolia has become an object of admiration rather than pity — as many may have viewed it for over half a century.

- The Korean Peninsula, Japan, and Taiwan are not included in the title of this topic. However, to complete the regional picture, it should be noted that the specter of major change looms for the Koreas, change, whenever and however it comes, that may profoundly alter the security framework of the region. North Korea's status as the raison deter for U.S. alliances could awkwardly 
come into serious question. Japan's security role and the future shape of the U.S.-Japan alliance has already changed in important ways and is today topics of intense discussion. Taiwan's ultimate status remains in limbo, but this impressive island is for the first time being governed by a party other than the Kuomintang and is, after years as an economic marvel, weathering significant economic distress along with the duress it endures from Beijing.

As demonstrated by this quick review of stunning changes, it would surely be presumptuous to attempt to forecast what the coming decade will bring for the region. It might be somewhat more realistic, and useful, to attempt to come to grips with some of the factors that seem likely to be of paramount interest in this region in the coming years. It is also unrealistic to pretend that one could make an exhaustive list of such factors in an area and era of such dynamic change. The task is, however, made more manageable by peering across the region from the perspective of Mongolia. It is, therefore, useful to envision Mongolia as a possible link to stability across the region, as the title of this event asserts, or at least a unique observation post. Mongolia's geo-political situation makes the perspective from Ulaanbaatar a valuable lens through which to view and project factors that may give us insight into the coming decade.

\section{The Russia-Mongolia-China Sandwich}

Although we hear often, maybe too often, of Mongolia's is sandwiched between giant Russia and huge China, th at concept is an appropriate place to start looking for pertinent factors. To strike an optimistic note, the prospect of a Chinese or Russian military invasion of Mongolia by either conventional or imaginative means is, fortunately, not a matter of realistic concern in today's world. It should be noted, however, that this favorable situation is not something to be taken lightly. Russia's current lack of interest in repeating the intrusive and oppressive actions of the Soviet Union is worth subtly (or bluntly) reinforcing at every appropriate opportunity. The degree to which Moscow's present lack of military capability to undertake such a move is part of the calculus is something that Ulaanbaatar and other capitals should contemplate. This is not to suggest that a stronger, richer Russia will be a more dangerous and aggressive Russia, but it is to suggest that working quietly now and in the coming years to influence the direction and character of a rebuilding Russia is a worthwhile endeavor for all involved, and a matter of special concern to Ulaanbaatar. There may be an art worth cultivating in keeping things favorable in this regard. Somewhat similarly, it is profoundly comforting for Mongolia to 
be realistically relaxed despite the proximity of the modernizing Chinese People's Liberation Army of 2.4 million people, the largest standing army on earth. Chinese statements that it is not an expansionist or aggressive nation are to be encouraged, whether wholly believed or not. Beijing should be encouraged to restate, believe, and fully internalize its own rhetoric with respect to opposition to troops of any nation on foreign soil and to China's having no extraterritorial ambitions. That makes it harder for China to rationalize any future action that might involve military activities and Mongolia — although already a highly unlikely prospect. Ulaanbaatar is a good lens, not yet fully utilized, through which to focus some of the world's interest in amplifying the concept of emerging China as a constructive and responsible member of the community of nationsa slogan that seems to resonate widely within China and elsewhere.

There is a broader aspect to this matter of China and its military forces. In the world media, much attention is given to the modernization and strengthening of the PLA, to China's military buildup. It often seems that inadequate attention is given to China's economic modernization and buildup. In any case, there is unquestionably value in further examination of the relative degrees to which China is choosing to utilize these two elements of its comprehensive national power. One can speculate with a good measure of confidence that competent, insightful Chinese leaders like Premier Zhu Rongji and Vice President (and probable future president) $\mathrm{Hu}$ Jintao, recognize that China's domestic and international success has been a consequence directly and overwhelmingly of its extraordinary economic development and not from its problematic military modernization. To illustrate the point dramatically, it was stunning for veterans of the Cold War to see China turn the tables on Russia, coming out on top economically and achieving more social stability — and doing it altogether on the strength of consistent national economic growth, without a shot fired.

There is no question that the current military of Mongolia's giant southern neighbor is significantly better than that of two decades ago, but the PLA is not a modern, advanced fighting force in a league with the United States, or even Japan and several Western European countries. China continues to struggle to obtain and assimilate technology and seemingly to flounder in its effort to develop doctrine and conduct the joint training essential for the modern battle space. For example, it appears to some experienced observers that China's inability to employ systems integration techniques, an aspect of technology central to modern war fighting, may lead to China's striving mightily for the next decade only to end up farther behind truly modern militaries than it is today- 
generally thought to be a gap of about 20 years. This is not to say that the PLA is failing to enhance steadily its capability to act against Taiwan if so directed by the Central Military Commission, but it is to say that China's military modernization success has been modest by world standards - while its economic growth has been phenomenal by any standard. When looking to their strengths, China's leaders can be far more assured that China's security can be protected by economic rather than military means, that China's arsenal of economic weapons or tools is far superior to its military arsenal - and almost certainly more efficacious and immensely less provocative and risky to national well-being. For Chinese leaders, the obvious choice in almost every contingency save Taiwan would be arrows from the economic quiver. (Of course, the economic aspect should not be disregarded with respect to Taiwan. It can be hoped that the coming decade will see far greater appreciation by Chinese leaders that economic factors are, and increasingly should be, paramount, with respect to Taiwan — and that a military solution would not only be almost certainly a counterproductive folly but also devastating to the economic progress of which China is so justifiably proud.)

China's troublesome lack of transparency with respect to its national decisions makes it difficult to draw conclusions about its likely national security decisions over the next decade, but, nevertheless, it is instructive to consider China's past actions and prospective options with respect to security concerns in the South China Sea, the Korean Peninsula, and the Central Asian Republics. Great, and continuing, attention has been directed to Chinese actions at Mischief Reef in the Spratly Islands. This has been based primarily on Philippine consternation (supported by conservative U.S. congressmen) at China's building there of facilities the Chinese claimed were for the use of fishermen but that Manila said had a military purpose. That incident was in February 1995, over seven years ago. Since that time, Beijing, other than improving the Mischief Reef facilities, has done little in the form of military action in the Spratly and Parcel Islands, although opportunities exist for it to act aggressively with what is clearly the vastly superior military capability in the area.

Instead, China has undertaken diplomatic and economic campaigns concerning the South China Sea and with its Southeast Asian neighbors, including solid work in the Asian Regional Forum, talks about a code of conduct to handle South China Sea territorial disputes, the resolution of disputed claims with Vietnam, and the continuing proposal for joint development in the South China Sea while setting aside the sovereignty issue. This is not all we might wish of China, but, looked at another way, China's conduct is far better than might be expected. 
That trend should be acknowledged and bolstered, even viewed on balance as a good example of how disputed issues and old antagonisms might be discussed and handled in the more northern reaches of East Asia.

On the Korean Peninsula, Beijing, to the consternation of Pyongyang, developed extensive trade relations with its former Korean War enemy, the Republic of Korea, and then in 1992 established diplomatic relations with Seoul. This was followed by stinging, pointed public declarations to Pyongyang that it would not back North Korea in an attack on the South. As a result, Beijing has derived important trade and investment from South Korea while propping up North Korea with food and energy needs. Among China's goals is preserving the flow of South Korea investment to China, or, put another way, keeping Seoul from having to divert its available investment funds to a collapsed North Korea. Some might see this as self-serving, but, unquestionably, China has chosen the economic path rather than a military one to further its interests and protect its security with respect to yet another problem area for China. Chinese interlocutors say that Beijing views the Korean Peninsula through an economic magnifying glass while Washington sees it through military binoculars. Americans need not take offense at the accusation but rather might encourage China's positive image of itself and its action concerning Korea.

Possibly the most pertinent example of Chinese conduct along these lines, as viewed from Ulaanbaatar, has been Beijing's handling of the long-standing unrest in the Xinjiang Uighur Autonomous Region of far northwest China. An independence movement in Xinjiang has received considerable support from dissident elements within Kazakhstan and possibly other Central Asian Republics. The matter of Beijing's handling of dissent in Xinjiang has recently received some notice in connection with China's reaction to the U.S. war on terrorism. Chinese leaders and security specialists are quick to point out that China has long been fighting Islamic fundamentalism in Xinjiang; the U.S. is a latecomer to the battle, they note, although admittedly having begun its fight under the very dramatic impetus of the events of September 11, 2001. The next point the Chinese rush to make is that the U.S. is prone to diminish the threat posed by separatists in Xinjiang, and that many Americans tend to view these dissidents as legitimately pursuing political causes. Beijing objects to Americans making these distinctions among terrorists. However, the central point here is not this difference with the U.S. but rather how, through what means, China has elected to deal with this threat to its national security and territorial integrity- especially how it is dealing with the external component of the threat.One might reflect on China's actions in 1962 when it attacked India in connection with 
border disputes and the events of 1979 when China invaded Vietnam to teach it a lesson concerning Cambodia. Such reflection might lead one to conclude that China is quite prone to employ the PLA across its borders. Indeed, China has used force rather brutally in reaction to dissident activities within Xinjiang. Yet China, as best we can ascertain, did not give serious consideration to sending the PLA across the border into Kazakhstan to "aid" authorities there in coping with the United National Revolutionary Front, which seeks to remove the Han Chinese population from Xinjiang and to establish an independent Islamic Republic of East Turkestan - an earlier name for what the Chinese call Xinjiang. This may be all the more noteworthy since there did exist boundary disputes between China and Kazakhstan until Presidents Jiang and Nazarbayev in 1998 signed an agreement resolving those issues. These border disputes, or other matters, could have been handily construed by authoritarian Beijing as a rationale for the dispatch of the PLA into Kazakhstan, if Beijing had decided to bother to justify an intrusion.

Beijing instead chose the dual path of diplomatic agreements and the promise, if not necessarily the full reality, of economic benefits. In the late 1990s, treaties among the Shanghai Five (China, Russia, Kazakhstan, Kyrgyzstan, and Tajikistan) resulted in troop reductions near borders, confidence-building measures, and collaboration to fight organized crime and, very significantly, to combat political separatism. Meshed with these treaties were bilateral agreements between China and Kazakhstan. These included resolving border disputes and providing for a prospective 9.5-billion-dollar oil and pipeline deal and a 15 -year economic program including a proposed automobile plant, electrical power transmission arrangements, Chinese investment in Kazakhstan, and construction work by China in the new Kazakh capital city. ${ }^{2}$

So, China has continued within its borders to use military force against this independence movement, but beyond its border the choice was non-military means, with emphasis given to the influence of economic leverage. One can cynically, and possibly accurately, point to the low probability that all these economic deals will be realized, but, at the same time, the clear choice by Beijing of economic rather than military means to handle this major problem is noteworthy as we look ahead to how China may respond in the future to threats, even pressing and provocative threats, to its security from, or related to, neighboring countries. Mongolians can be pleased that Chinese recipes for the region, in-

${ }^{2}$ For a fuller examination of the Xinjiang-East Turkestan issue, see Eric A. Mc Vadon, "China, the Central Asian Republics, Russia, and Mongolia" in The Mongolian Journal of International Affairs, No. 6, 1999, pp. 35-39; Center of International Studies, Ulaanbaatar. 
cluding those directly involving Mongolia, are almost certainly to consist primarily of economic ingredients, with a diplomatic coating as a sweetener but not much of a military flavor. Much the same thing can be said for Russian initiatives, as alluded to at the outset.

Yet this does not imply that Mongolia and other nations in the region are, or should be, altogether relaxed at this prospect. There is natural and justifiable apprehension that the imbalance in size, reach, and experience of the economies and entrepreneurial entities of Russia and China may create serious problems lor the smaller, more limited, and less experienced Mongolians. Put succinctly, it is altogether reasonable to entertain abiding concern in dealing with these neighboring behemoths. In this imbalanced situation, even well-intentioned actions may intentionally or casually ignore, or be oblivious to, important concerns and interests of Mongolia. Moreover, Russia is economically fragile, even unstable, and prone to desperate acts; China is not only making bold economic reforms while trying to hold the line on political reform but is also newly engaged in adjusting to WTO membership, with all the internal stresses that may produceor, at the very least, that many in China fear it may produce. This creates an environment in both countries where the unscrupulous or uncaring may, in acts of desperation or greed, elect to sacrifice Mongolia's interests, or those of other countries or partners, in order to gain some short-term advantage in a complex economic scramble.

Some observers have said, only half jokingly, that Mongolians have good reason to fear that Mongolia may become entangled in deals with Russia where the Russians promise much, deliver little, and leave Mongolia holding the bag wondering where the money went and where to go from there. Looking southward, the concern is that China may promise much and eagerly deliver much more than it promises, leaving Mongolians wondering how to cope with an overwhelming intrusion that has gotten out of control or simply become suffocating. Not to be ignored is another prospect, a possible corollary to this specter of pervasive Chinese influence, that Mongolia could become a conveniently circuitous path or stepping stone for massive Chinese economic and population movement into the Russian Far East. Mongolians, forearmed with a full appreciation of these possible pitfalls, can more safely find a path of economic cooperation and growth that takes appropriate advantage of Russian and Chinese enthusiasm but minimizes the risks of disaster for the smaller partner. 


\section{The Central Asian States: Insights for Mongolia}

Was the Shanghai Cooperation Organization ( $\mathrm{SCO}$ ) relegated to the dustbin by being essentially ignored when that part of the world became center stage in the fall of 2001, as Washington undertook its war on terrorism? Possibly more will be heard in the future of the SCO, the successor body to the Shanghai Five with the addition in June 2001 of Uzbekistan to the original group of China, Russia, Kazakhstan, Kyrgyzstan, and Tajikistan. ${ }^{3}$ Beijing made an effort to rejuvenate the group by convening an ad hoc meeting of the foreign ministers of the expanded group in Beijing in January 2002, four months after the attacks on the World Trade Center in New York. The purpose of the meeting, as announced by the Chinese Foreign Ministry, was to discuss Afghanistan's future and the war on terrorism as well as the struggle against religious extremism, separatism and terrorism in each of the member states. ${ }^{4}$ China's battle to sustain the vitality of the SCO is steeply uphill in the face of the distractions of the ongoing military and political drama in Afghanistan and its intense spin-off swirling into most of the other states plus Pakistan.

Ulaanbaatar, watching this process, understandably might conclude as a general matter that linking one's future to arrangements with Beijing and Moscow is an undertaking of dubious value, that there seems more to gain from ties to and cooperation with the United States, the rest of the Western nations, and Japan. Or, put another way, the U.S., along with its various allies and partners, are undoubtedly the central actors in what history may describe as the first war against the nontraditional threats that we have been told may shape future warfare: that these are the threats we will all have to cope with in the coming decade and beyond.

However, the truly pertinent lesson for national leaders and strategic thinkers in Ulaanbaatar may have less to do with choosing the right side than with contemplating the issue of nontraditional threats to national security as core concerns for Mongolia — and the implications thereof - and specifically the implications of what is now transpiring in Central Asia. Security specialists and military officials have for at least a decade been intensely interested in this

New form of threat to the security of nations and to regional and global stability. There has been, for example, concern about how best to arm, structure,

\footnotetext{
${ }^{3}$ Interestingly, these original three "-stands" in the Shanghai Five each border China, as incidentally do Afghanistan and Pakistan. Of all these five former Soviet Republics plus Afghanistan and Pakistan, only Kazakhstan borders Russia.

4 “China to hold meet on Afghanistan's future," Reuters news report, Beijing, December 25, 2001
} 
and position forces based on uncertainty about the nature of future threats. Should planning contemplate retaining significant legacy forces in expectation of the persistence of what might be termed conventional or "legacy" threats; e.g., attacks by the militaries of one nation against another or of armed insurrectionists against governments? Or do new, nontraditional threats comprise the primary body of concerns against which prudent leaders should plan? What balance should be struck? The frequently described nontraditional threats consisted of, presciently, international terrorism as well as transnational crime including smuggling of goods and people; the flow of drugs and arms; rampant piracy in Asian waters; and cyber attacks ranging all the way up to damaging intrusions into national or global financial networks, multinational corporations, and even major governments and their agencies.

One can imagine other forms of threat along these lines; indeed, one cannot be confident of an ability to imagine how long the list might be, forecasting the likely general category of the next major category that might appear, or guessing the precise nature, target, and scope of the threat. Further to complicate matters, threats of this nature can blend at both ends of the spectrum into old-fashioned organized or individual crime or into insurrection or low-intensity conflict — or branch out in other ways. It is exceedingly difficult for nations large and small to grasp the complex implications of nontraditional threats, as well as to determine how much residual attention must be given to traditional threats.

Mongolia has at least three advantages in regard to these complications: (1) It is not currently an obvious target of any nontraditional threat, and the nature of its national activities seems to make the chances slight that it would, itself, come into the sights of international terrorists - the obvious current category of concern. (2) As explained in the previous section, Mongolia is not the likely object of conventional or traditional threats from its large neighbors, or others. (3) Mongolia has the luxury now to observe closely what is occurring in the Central Asian states to its west. ${ }^{5}$ Observation and analysis of that which is transpiring in the six "-stans" immediately west of Mongolia provides Ulaanbaatar with an opportunity to look ahead at factors with respect to nontraditional threats that may be of import to Mongolia in the coming decade.

There is much more going on in these Central Asian states, including Afghanistan, than the very visible final throes of the battle between U.S. and local forces and residual Al Qaeda terrorists and the Taliban. As described in the

${ }^{5}$ The proximity of Mongolia to this area should be noted. The closest of these countries, Kazakhstan, does not actually border Mongolia but is only about 25 miles or 40 kilometers away, albeit not directly connected in that mountainous area by road or rail. 
March-April issue of Foreign Affairs, "Beyond terrorism, the war in Afghanistan has turned a spotlight on other acute threats to Central Asian stability, including the uninterrupted flows of insurgents, drugs, weapons, and refugees across the region's porous borders. Indeed, although the Soviet Union's collapse brought internationally recognized boundaries to Afghanistan and the Central Asian states, in practice these national boundaries are extremely permeable." ${ }^{6}$ There is also occurring in these states the large-scale introduction of Western combat troops, support forces, peacekeepers, technicians, advisers, aid workers, and many others; additionally there is the influx of monetary and material aid and all the attention, intrusion, and influence inherent in that.

The environment in those states that has been so conducive to the thriving unsavory activities listed above - and others, compounded in some cases by government involvement, support, or acquiescence, will be altered, and possibly changed radically. Some of these activities may survive in place; others will look for new homes, new ways of doing business, and new opportunities. Although certainly not specifically mentioning Mongolia, Deputy Secretary of Defense Paul Wolfowitz and other senior Pentagon officials warned recently that the war on terrorism could lead to military activity in nations that have large ungovernable regions, using Somalia and Yemen as examples. ${ }^{7}$ No one would place Mongolia in the same category as the two countries cited as possible examples, but the allusion to large, remote areas that may be difficult for a central government to monitor closely and control stringently is at least a reminder of vulnerability when these factors exist. And there is the compounding factor of geographic proximity to areas rife with troublesome activities and factions.

So, here is another challenge to Ulaanbaatar for the coming decade: Ensure that Mongolia is not a tempting alternative location for those conducting undesirable activities and who may feel exposed in the new spotlight on the region or become genuinely threatened as they try to hang on in the countries to the west of Mongolia. It is not necessarily that large-scale arms or drugs shipments would flow through Mongolia but rather that Mongolia might be seen as a quiet and remote sanctuary for those people and organizations that direct such activities and profit there from - meaning, incidentally, that some Mongolians, in a difficult economic environment, might find it tempting to shield or facilitate nefarious operations of this sort. (And here it is appropriate to glance

${ }^{6}$ Pauline Jones Luong and Erika Weinthal, "New Friend, New Fears in Central Asia," Foreign Affairs, March-April 2002, p. 65. Council on Foreign Relations, New York. ${ }^{7}$ Jason Sherman, "Pentagon to Review Unconventional Defenses," Defense News, March 25-31, 2002, p.4. Army Times Publishing Co., Springfield, Virginia. 
again at Russia and China and recognize that, as it becomes more difficult to get away with such nefarious activities in these countries, that Mongolia would be an option for Russian and Chinese arms proliferators, smugglers, and other international criminals or other unsavory characters, if it seemed that the Mongolian authorities would not be alert to their moving into that country in one way or another.)

There is, of course, also the prospect that terrorism in some modified new form could take root in Mongolia to escape the pressures being placed on such activities in much of the more developed world.

This, at a minimum, argues for vigilance on the part of the Mongolian government, armed forces, and other internal security organizations to ensure that Ulaanbaatar does not awaken to this reality someday in the future. We witnessed in the last decade the hijacking of Afghanistan, an arid, mountainous, remote, landlocked country of more than 16 million hardy and resilient people, many of whom are nomadic and many of whom are impoverished. Although it is not suggested that Mongolia's future is threatened in this way, or that the national circumstances are similar, attention is warranted in Ulaanbaatar to these factors that might affect the future of an isolated, mountainous, arid country with no coastline and a much smaller population of less than 3 million hardy and resilient people who are striving to improve their economic lot and to find a way for their country to make a mark in the world.

Mongolians have every reason to continue to be proud of their accomplishments and justifiably optimistic about their future and that of their country, and this is especially the case if they are astute in recognizing the unique aspects for their country of what is transpiring near them and appreciating how best to avoid or fend off facets of this new genre of nontraditional threats that could dim that bright future. 